Crime, Histoire \& Sociétés / Crime, History \& Societies

vol. $22, n^{\circ} 2 \mid 2018$

Cesare Lombroso (1835-1909)

\title{
Lombroso: The Myth,The History
}

\section{Silvano Montaldo}

\section{(2) OpenEdition}

\section{Journals}

Electronic version

URL: http://journals.openedition.org/chs/2283

DOI: $10.4000 /$ chs.2283

ISSN: 1663-4837

\section{Publisher}

Librairie Droz

\section{Printed version}

Date of publication: 31 December 2018

Number of pages: 31-61

ISSN: $1422-0857$

\section{Electronic reference}

Silvano Montaldo, "Lombroso: The Myth,The History", Crime, Histoire \& Sociétés / Crime, History \& Societies [Online], vol. 22, n² | 2018, Online since 31 December 2020, connection on 13 April 2021. URL: http://journals.openedition.org/chs/2283 ; DOI: https://doi.org/10.4000/chs.2283

This text was automatically generated on 13 April 2021.

(C) Droz 


\title{
Lombroso: The Myth,The History
}

\author{
Silvano Montaldo
}

\section{Introduction}

During his final days, in October 1909, while writing the preface to an English volume containing a summation of criminal anthropology, Cesare Lombroso looked back over the years to help his American readers understand "how the first outlines of this science arose in my mind." ${ }^{1}$ For some time, the father of criminal anthropology had begun to recount the tales of his discoveries, and in his brief accounts he was not always honest. ${ }^{2}$ To the Americans, for example, he claimed that he had met the famous bandit Giuseppe Villella in prison and that later, when carrying out the man's postmortem, he had noticed the median occipital dimple whose "discovery" led him to deduce his theory of criminal atavism. ${ }^{3}$ Nowadays, we know that things happened very differently: Lombroso was his own first, and unreliable, historian. ${ }^{4}$ Nor can we expect to find greater accuracy in the accounts written by his collaborators: those of his daughters Paola and Gina (the guardian angel of the Lombroso myth) as well as those of Hans Kurella, the man who popularised Lombroso's work in Germany, (leading to an eventual English translation in 1911)..$^{5}$

2 This article aims to outline the way that the historical memory of the Italian anthropologist was constructed, starting from the period immediately following his death. It will also investigate the various meanings attributed to the science of criminology pioneered by Lombroso, and will consider the position that he, as a positivist, free thinker, socialist and Jew, has assumed in public opinion from the start of the twentieth century to today. The analysis begins by looking at the efforts made by the anthropologist, his relatives and close collaborators, during and just after his final years, to create an image of a philanthropic and brilliant man responsible for the invention of criminology. It then investigates the uses made of Lombroso in the years of Italian fascism and the immediate postwar period, highlighting their ambiguities and ideological contrasts. Next, the article considers the debate initiated by American sociologists and criminologists on the Italian's true place in the history of the study of 
criminality. It then shows how, after a period of relative disinterest in his work, Lombroso was rediscovered in the 1970s and portrayed as one of the principal spokespeople of a bourgeois, misogynist and racist ideology. Finally, the article examines how, as the more militant and teleological interpretations were attenuated in the following decade, a series of studies based on more solid foundations began to appear. These shed light on previously neglected aspects of Lombroso's work and brought about the widespread international attention that the intellectual currently receives.

3 The article focusses principally on Italy and the United States, the countries in which Lombroso has been most prominent and from where the main historiographical contributions have come. It refers to, but does not foreground, the cases of France (where the debate on criminal anthropology played an important role only in the last two decades of the nineteenth century) and Britain (where Lombroso's work never really inspired further research and debate after the Goring book). ${ }^{6}$

\section{The aftermath of Lombroso's death: "The great benefactor of the people"}

4 During the period immediately following Lombroso's death, books by his daughter Gina and by Hans Kurella played a key role in determining how criminal anthropology was remembered, for two main reasons. Firstly, they constituted an eyewitness account by people who were in direct contact with Lombroso and to whom we owe information that would otherwise have been lost. Secondly, they gained widespread circulation and influenced the majority of subsequent commentators, even on occasion those active today. Scholars, journalists and other anthropologists often copied entire passages from these works, taking inspiration from their colourful anecdotes and uncritically adopting their viewpoints.

5 In addition to her books, Gina, who was her father's secretary for two decades, compiled the first (albeit incomplete) bibliographical records of Lombroso's immense opus. ${ }^{7}$ A graduate in literature and philosophy, as well as in medicine, writer and wife of the historian Guglielmo Ferrero, Gina endeavoured to recover the documentary legacy that her father had partly depleted and dispersed. She collected all that had been saved, tried to identify the recipients of letters of which there were only drafts, and published some of her father's letters preserved in the library of Verona. ${ }^{8}$

6 At the same time, however, and with the help of her sister, Gina also assembled a biography oriented to certain specific objectives. In the first instance, this was intended to consolidate her father's reputation as the founder of criminology and to defend him from his opponents' many attacks. Next, it aimed to commemorate him as a great human benefactor driven by philanthropic ideals. Lastly, it used the most original aspects of his character to demonstrate the validity of the theory that saw genius as a product of an evolutionary degeneration. Following her father's original formulation, Gina had used the theory in her university thesis, which was published in $1904 .{ }^{9}$

7 Gina was driven by a strong sense of filial devotion - not entirely shared by her sister Paola, who was often critical of her father's ideas on women - but she was also motivated by a real interest in the development of criminal biology. This was something that she shared with her brother-in-law Mario Carrara, who succeeded 
Lombroso in his professorship and as director of the Museum of Criminal Anthropology, as editor of the journal Archivio di Psichiatria ("Archive of Psychiatry"), and as the judge of the Lombroso Prize, which the family had instituted to reward those who most furthered the study of criminology. ${ }^{10}$

Kurella, Lombroso's German translator, had similar objectives, but had little interest in biographical details. Instead, he concentrated on trying to document Lombroso's impact on European positivism and on providing an up-to-date synthesis of his research in such fields as psychiatry and political crime, including his studies of genius and those of prostitution and female criminality. ${ }^{11} \mathrm{He}$ also underlined that Lombroso had never become a "fanatical advocate of racial breeding", like Joseph de Gobineau or Houston Stewart Chamberlain, because he was aware of the importance of the Jewish contribution to Mediterranean civilisations and of the ethnically mixed composition of the Italians. ${ }^{12}$

9 Shortly before and after the criminologist's death, some of his other collaborators published histories of criminal anthropology, as well as reflections on his work and his influence on late nineteenth-century science, methods of policing and the penal system. Overall, however, these were authors directly involved in criminal anthropology and lacking the mindset of a historian. ${ }^{13}$ The exception was the German sociologist and political scientist Robert Michels. Turinese by adoption and a frequent visitor to Lombroso's home, in this period Michels published his Note sull'uomo politico $e$ sull'uomo privato ("Notes on the Political Man and Private Man"), a useful testimony to the anthropologist's complicated relationship with political life. ${ }^{14}$

10 All of these family members, followers and friends wrote their contributions in the period of profound crisis immediately before and after Lombroso's demise. This had been brought about by the decline of the positivist ideology, of evolutionary socialism and of the potentiality of criminal anthropology, but was also the result of the rise of new intellectual movements ready to take advantage of Lombroso's scientific weaknesses in order to undermine the cultural and political grouping that he had served as a reference point. Lombroso's traditional opponents, including liberal jurists determined not to allow criminal anthropologists an institutional role and criminologists who held different views to him, like Luigi Lucchini, Alexandre Lacassagne and Franz von Liszt, were still vocal. However, they were now joined by men of letters who increasingly tended to identify themselves with the aestheticising theories of cultural avant-gardes, which held that the psychiatric approach to the lives of great writers was overly focused on mass audiences. ${ }^{15}$ In addition, Lombroso, among the most important members of the Associazione del Libero Pensiero (Association of Free Thinking), had for some time been a target of the Jesuits writing in La Civiltà cattolica ("The Catholic Civilisation"), a semi-official Vatican publication, and of right-wing thinkers who accused him of heading a subversive Judaic-Masonic conspiracy, of refuting free will and of compromising the dignity of man by muddying the notion of genius. ${ }^{16}$

11 As a result of bitter arguments with reactionary circles, after declaring his adherence to socialism in 1893 Lombroso became an emblem for many members of the Italian extreme left. He would remain so for a long time despite some of his ideas being incompatible with those of the socialist movement, which in Italy had in any case many internal variations. ${ }^{17}$ One episode in particular can serve to highlight the extent to which Lombroso's image had become overlaid by political significance. On 21 February 
1910 the Teatro Balbo of Turin was to host a conference featuring Agostino Gemelli, one of many stages of a tour in which the Franciscan friar and physician figuratively announced Lombroso's funeral and that of his doctrine. ${ }^{18}$ The event, which was due to be attended by a large company of Piedmontese clergy, could not go ahead because a crowd of around 150 people composed mainly of university students and militant socialists broke in, crying "Viva Lombroso!" While Gemelli took refuge in a convent, the bitter confrontation between the two groups continued in the streets of Turin, where Lombroso's sympathisers distributed handbills extolling the "great benefactor of the people." ${ }^{19}$

The early crisis of criminal anthropology and the atmosphere of open hostility around the time of his death thus provided the context in which an historical account of Lombroso's work was first laid out, an undertaking to which he personally contributed with the intent of establishing himself as the founding father of criminological studies worldwide. This image persisted in Italy for many years, while in other countries, as we will see, it failed to endure beyond the 1930s.

\section{Idealists, fascists, anti-semites and anti-fascists: 1910-1945}

13 In the years following Lombroso's death, Italian culture was dominated by the idealism of Benedetto Croce and Giovanni Gentile, who believed that the sciences, on a theoretical level, were subservient to philosophy, the only discipline entitled to elaborate general interpretations of the world. While not discounting his contribution to the renewal of the judicial system, these two philosophers openly attacked Lombroso for his crude materialism and inordinate generalisations, making him a symbol of the late nineteenth-century crisis of Italian thought that lasted until the idealist rebirth. ${ }^{20}$ His passing marked the end of an era that seemed ever more distant: a gigantic, enduring shadow fell over the anthropologist, obscuring him from the gaze of high culture, which for decades was unable to establish a dialogue with the scientific thought and to recognise its ethical and political importance, except when it took a nationalist viewpoint, celebrating Italian pioneers, real or imagined.

By contrast, the fascist regime's attitude towards Lombroso was somewhat more ambiguous, owing to the diverse character of the dictatorship and its internal twists and turns. The racist extreme right could not fail to consider him a polemical target, as a Jew, socialist and one of the first to highlight the dangers of anti-Semitism. ${ }^{21}$ His family was therefore persecuted by the regime, first for being anti-fascists, and later for being Jews: Paola Lombroso and her husband Mario Carrara, as well Mario's brother Enrico and the couple's son-in-law Guglielmo Ferrero all signed the 1925 Manifesto of the Anti-Fascist Intellectuals. ${ }^{22}$ Subjected to police surveillance, Ferrero and his wife Gina Lombroso moved to Switzerland in 1930, where their home in Geneva became a safe haven for Italian political exiles. Carrara, a professor in forensic medicine and the director of the Museum of Criminal Anthropology after Lombroso, was one of twelve university professors who in 1931 refused to swear the oath of allegiance imposed by the regime. He also took part in the international protest against the imposition and was expelled from teaching and from the museum. ${ }^{23}$ Carrara welcomed anyone who was opposed to or mistrusted by the dictatorship to his Turin home, and in 1936 was jailed for subversive activity. After the introduction of the Italian Racial Laws in 1938, 
Paola's and Gina's books were banned as "Jewish literature", while their brother Ugo was dismissed from his position as professor at the University of Genoa and lived in hiding during the war. ${ }^{24}$

Despite all this, before the passing of the Racial Laws Lombroso's heirs issued statements on certain institutional innovations in the prevention, repression and punishment of crime, as well as on the spread of biological research into criminality in Italy and the rest of Europe, the Americas, the Soviet Union and even Nazi Germany (whose anti-Semitism they relentlessly denounced). Their comments presented the latest developments as successes attributable to the ideas of Lombroso, who had managed to shift the focus of penal action from an abstract conception of crime to one emphasising the delinquent individual. ${ }^{25}$

In addition, 1937 (the year of Carrara's death) saw the publication of the Manuale di Medicina legale ("Handbook of Forensic Medicine"), which he had written with some of his students and which became a textbook used in the training of generations of Italian doctors. The book reaffirmed the theories and classifications of Lombrosian criminal anthropology in the light of recent discoveries in the field of endocrinology. ${ }^{26}$ Both before 1922 and even more so during the dictatorship, the authors of this research, such as Nicola Pende, had made the most of Lombroso's emphasis on the delinquent to gain legitimacy in the eyes of political power. ${ }^{27}$

Some of Lombroso's other students, such as Salvatore Ottolenghi, introduced the principles of criminal biology into the policing system of Giolittian Italy before going on to collaborate with the fascist regime. The latter implemented a series of policies regarding children and issued codes of ethics inspired by both the welfare and repressive aspects of the positivist understanding of juvenile delinquency and prostitution..$^{28}$ Mary Gibson has shown how these scientists, who had abandoned the socialist and philanthropic ideals of their master, were able to adapt to the fascist dictatorship so easily, providing it with conceptual and operational tools. A decisive turning point was the period of nationalism and the First World War, during which Lombroso's heirs were deployed in democratic interventionism and in the military health service. ${ }^{29}$

Hated by the anti-Semites, derided as a thinker by the idealists but appreciated by them as the inventor of new methods of controlling criminality, celebrated as a founding father by the emerging group of endocrinologists (many of them convinced fascists), and the object of reverent homage by his students (despite their divisions over the dictatorship), Lombroso nevertheless remained one of the Italian geniuses celebrated by the regime until the official adoption of racism in 1938. In 1933, a panel of the Centro Nazionale delle Ricerche (National Research Centre, CNR) headed by Guglielmo Marconi included Lombroso on the list of illustrious Italian scientists to be represented at the Chicago Exhibition, and plaster casts and photographs of some of the objects and exhibits from the Turinese museum were thus sent to the USA, where they remain to this day..$^{30}$

Five years later, shortly before the enactment of the racial laws, Giuseppe Maggiore, president of the Fascist Institute of Culture, denounced Lombroso, Freud and Marx, as "proponents of the materialist Jewish culture of the nineteenth century." ${ }^{31}$ A year later, when Lombroso's name was deleted from the masthead of the Archivio di Psichiatria, which he had founded, Maggiore declared that the propositions of the positivist school had to be completely rejected. This was because they did not allow penal law to be 
based on the concept of race, given that the polygenetic theory of Italian descent clashed with the affirmation of racial purity desired by the regime..$^{32}$ Fascist prefects and mayors thereupon removed the name Lombroso from street signs and institutions in Turin, Verona and Novara. The monument that the city of Verona and his admirers had raised to him in 1921 was also removed at the end of 1942 and put in storage, still intact. $^{33}$

20 The destiny of this statue, first exhibited, then concealed but preserved, serves as an apt metaphor for the image of Lombroso during the fascist dictatorship. Nobody, however, whether idealists or anti-Semites, or fascist, anti-fascist or "grey" scientists, ever felt inclined to call into question the historical memory that Lombroso himself had constructed shortly before his death and which his daughter Gina continued to promote for the rest of her life, even to the point of planning a film on her father as a way of countering the surge in anti-Semitism..$^{34}$

\section{Chicago, 1937: two pioneers, but "too early"?}

21 The criminologists of Lombroso's period who challenged criminal anthropology did not, it seems, think to bring the conflict into the field of history. Many had a background in medicine, were psychiatrists, doctors and physical anthropologists, and shared with Lombroso a common frame of reference based on biology and determinism. ${ }^{35}$ Even those who had studied law, like Gabriel Tarde and Luigi Lucchini, were induced to reject in part or in full the scientific validity of Lombroso's theories, pointing out his methodological errors, his misuse of statistics, and the lack of rigour in his analogies. None of this, however, led to a debate on the history of criminology.

Even so, the grounds for such a discussion did exist. Thus the young Joseph van Kan, in his examination of the economic causes of criminality, considered Lombroso to be only one of many authors who had applied themselves to the subject, without bringing anything original or important to it. Indeed, van Kan rightly observed that there were substantial differences between the first edition of the Uomo delinquente ("Criminal Man") and the later ones, with alterations made in response to criticisms from the French concerning the influence of social factors. ${ }^{36}$ Van Kan's work marked out a path for Willem Adriaan Bonger, who became the first to formulate a Marxist theory of criminality. In his Criminalitè et conditions économiques (1905) Bonger published an extensive review of authors who had studied the relationship between delinquency and economic conditions. Lombroso and his followers were the subject of one of many entries, placed after that on social statistics and before that on the French environmental school. ${ }^{37}$ In short, there were those who could have cast doubt on the idea of Lombroso being the father of criminology, yet they did not do so. Joseph Lottin, author of the monumental biography of Adolphe Quetelet, published in 1912, fully understood the fundamental contribution to the study of criminality made by his compatriot, but he did not press the point because he was interested only in confirming the great Belgian statistician as the pioneer of sociology, and not of criminology..$^{38}$

It fell to two young students of the Chicago School, Alfred Lindesmith and Yale Levin, to launch the debate on the issue with an article titled "The Lombrosian Myth in Criminology," published in $1937 .{ }^{39}$ The spreading of Lombroso's ideas to the USA, starting in the late 1890s, had played a decisive role in the birth of North American criminology, and the Italian had been the main reference point for the first generation 
of American criminologists. Although strongly criticised by some, criminal anthropology was seen as a tool with which to attack the more dogmatic aspects of criminal law and to adapt the American justice system to the challenges of modern criminality. ${ }^{40}$ In 1909 the first national conference of criminology was held in Chicago, giving rise to the Institute for Criminal Law and Criminology, which later launched its own journal. A year earlier John Wigmore, Dean of the Northwestern Law School, had travelled to Turin to offer Lombroso a lectureship. Lombroso declined but recommended Wigmore ask Enrico Ferri, who accepted but delayed his departure in order to have time to perfect his English. The plan then fell apart for political reasons: the US ambassador to Rome advised against inviting Ferri, who he deemed to be "a hotheaded socialist." ${ }^{41}$

Nevertheless, the publication between 1895 and 1909 of four different editions of The Female Offender was followed in 1911 by two posthumous summaries of Lombrosian thought published in the USA. These were: Crime: Its Causes and Remedies, a book promoted by the aforementioned Institute of Criminal Law and Criminology, and Criminal Man, which was edited by Lombroso's daughter Gina. Lombroso's works also entered the canon of the early American eugenicists, alongside criminologists like Richard L. Dugdale and Henry H. Goddard ${ }^{42}$ In the following years, however, in the USA Lombroso's star was eclipsed by biological criminology theories of the feeble-minded delinquent, especially at Harvard. His ideas were given greater attention in the 1920s with the development of endocrinology, in the USA as in Italy, and the Criminobiological School in Germany. ${ }^{43}$

In those same years, however, Chicago became the cradle of new theories on criminal behaviour drawn from sociology, which had a regenerating effect on the international debate as a whole, spreading throughout postwar Europe. ${ }^{44}$ The Chicago University Department of Sociology was an extraordinary laboratory of innovation in which the idea that human behaviour is strictly conditioned by one's environmental roots and institutions was explored. Its studies denied the existence of any biological basis for crime and also rejected the hypothesis of a multi-factorial aetiology, which Lombroso had arrived at in the final stage of his life. After the publication in 1933 of a report on the state of criminology in America written by Jerome Michel and Mortimer Adler, which was extremely critical and aimed at the reformation of this field of studies through sociological research, a suitable environment for hosting a debate on the role of Lombroso in the history of studies on criminality was created..$^{45}$

And this is precisely what Lindesmith and Levin did, in response to certain publications that referred to "a Lombroso Renaissance" or a "New Criminal Anthropology" and traced a series of legal and custodial reforms back to his ideas. These included works by Hermann Mannheim, a German judge who had emigrated to escape Nazism and who played a dominant role in English criminology. ${ }^{46}$ For Lindesmith, who later became an authority on drug addiction and was placed under federal surveillance because of his unorthodox theories, and for Levin, who did not pursue an academic career, Lombroso and his school had absolutely not opened the road to the scientific study of criminality. On the contrary, they had caused a major setback in a debate which had begun in the eighteenth century with John Howard and Cesare Beccaria and which André-Michel Guerry and Quetelet had placed on a scientific basis by the 1830s. Making use of the reviews by van Kan and Bonger, ${ }^{47}$ Lindesmith and Levin followed a path that led to the environmental approach of the Chicago School. The notion that Lombroso was the 
father of criminology was for them an unfounded myth created by the first generation of American criminologists and thereafter accepted by sociologists due to "an almost incredible lack of historical perspective." ${ }^{48}$ In contrast, students of criminology in other countries, aware of how extensive and important the earlier debate had been, had rejected Lombrosian theories. This had not happened in the USA, where the lack of an indigenous tradition and the distance from European scholarship had aided the Lombrosians' attempts to trace the start of criminology to the Italian's ideas. ${ }^{49}$

It was therefore no longer a case of seeking out whatever good one could in criminal anthropology, because nothing was worth preserving. Rather it was necessary to determine on what bases American criminology had been built. According to Lindesmith and Levin, a series of cultural factors (the spread of individualism and faith in equal opportunities), theories (the psychology of William James and Darwinian evolutionism), and institutional innovations (the introduction of intelligence tests, the foundation of the Institute of Criminal Law and Criminology) had combined to create an extremely receptive situation for criminal anthropology. American ignorance of the controversies unleashed in Europe against Lombroso, the translation from Italian of his and his followers' works, and an effective communications strategy that branded all studies preceding Uomo delinquente ("Criminal Man") unscientific all helped certain doctors and psychiatrists use criminal anthropology to create for themselves a professional space in the American justice system and in the public debate. They were further aided in this endeavour by a level of propaganda and militancy.

At this point Lindesmith and Levin contradicted themselves, because they admitted that a debate had existed also in America, one animated by philanthropists, magistrates, journalists, officials, and scholars of social problems. In other words, even in the USA there had been intellectual traditions that refused to accept Lombroso's propositions. Nevertheless, the two authors' intervention raised the problem of the exchange of personnel that had occurred through the spread of criminal anthropology. It also pointed out the political and cultural context that had favoured its acclimatisation, the way that doctors and psychiatrists had rewritten the history of these studies, and the consequences that this had had on the way in which crime had been studied and tackled in the USA.

The two also cast a glance over the Atlantic: in Europe the clash over Lombroso's propositions had been intense and had crystallised into competing schools before following the division determined by certain professions: the conflict between those in favour and those in opposition to Lombroso heightened antagonisms between interest groups in the judiciary, in jurisprudence, in criminology and in forensic medicine. ${ }^{50}$ Criminal anthropology's ability to gain purchase may in fact have been a result of a phase of low confidence in prison reforms and a period of social alarm over worsening public order. Lombroso, by identifying the individuality of the delinquent as the main driver of antisocial behaviour, had offered the ruling classes an easy way out of their responsibilities for the problems caused by poverty and marginalisation. The developments of criminology ended up contradicting the triumphal visions of scientific thought: the setback caused by criminal anthropology showed that science did not always follow a linear process of evolution in compliance with logical argument that led ever closer to the truth, since it could also go down blind alleys. ${ }^{51}$

A significant response to the Lombrosian Myth was provided by the Thorsten Sellin, a sociologist at the University of Pennsylvania who was an expert in criminal statistics 
and editor of the Annals of the American Academy of Political and Social Science. Sellin had spent time in Italy and come into contact with those endocrinologists who were (to his mind) successfully augmenting criminal anthropology. To his mind the two young Americans had been unfair to Lombroso, and had also failed to say anything about the contemporary state of sociology. Many of the methodological errors that they ascribed to Lombroso, such as the inadequate use of control groups, continued to be made by many of their colleagues. Furthermore, social research had not been interrupted by criminal anthropology, even though the irruption of the latter had overshadowed it for quite some time. But this was not Lombroso's fault. Rather, it was a weakness of sociology. According to Sellin, Lombroso was not the father of social studies on crime, nor was he to be considered the initiator of biological research on the delinquent. His importance instead resided in the unprecedented impulse he had brought to the study of the criminal, an impetus that, even if it had led many to overvalue his theories, had nonetheless attracted the attention of hundreds of new researchers, thus laying the foundations for the institutionalisation of new disciplines. ${ }^{52}$

\section{Lombroso after the Second World War: 1945-1970}

31 In the following years (and to an extent up to the present day) two forces within American criminology continued to take occasional positions on Lombroso: the bigger faction, dominated by sociologists, were disdainful of his contribution and used him to attack the minority grouping, which was composed of biological researchers, or else to denounce the backwardness of criminological studies in Europe and Latin America. ${ }^{53}$ The latter did not come to Lombroso's defence, but instead highlighted his methodological errors in order to claim credit as a solid, up-to-date branch of scientific research. ${ }^{54}$ In the background were the forced sterilisation procedures introduced by eugenics, and the general disrepute that adhered to European criminology following its collaboration with totalitarian regimes. ${ }^{55}$

Despite his critics, Lombroso was included in the prosopographical collection conceived by Mannheim in the 1950s, Pioneers in Criminology. The section on Lombroso was assigned to Marvin Wolfgang, a pupil of Sellin who was working on an integrated theory of criminological research and had in the past spent time in Italy as a Guggenheim fellow and had met researchers working in the field of clinical criminology. Wolfgang, who would go on to become one of the most influential criminologists in the English-speaking world, reiterated several aspects of Sellin's reflections on Lombroso. He argued that both the biological orientation that prevailed in European criminology and the predominant environmental approach of America reflected two different outcomes of Lombrosian thought, which contained both perspectives. ${ }^{56}$ The image of Lombroso was, however, very different on either side of the Atlantic: while still appreciated in Europe, particularly in Italy, in the USA he had often been an object of derision and denunciation, used as "a straw man for attacks on biological analyses." ${ }^{57}$

Wolfgang's intervention was aimed more at demonstrating Lombroso's proximity to the multiple-factor analysis of those years than at proposing new lines of interpretation. For example, while dedicating ample space to biographical matters, he limited himself to repeating what Kurella had written half a century before. Using the historical information provided by Lombroso's followers, he identified a tradition 
drawn largely from medicine and the natural sciences to which Lombroso had reestablished ties. In addition, although Wolfgang analysed in detail the methodological errors made by the Italian, he adopted the defensive strategy previously devised by Sellin, making light of the mistakes and demonstrating that they were common to research of his time.

The portrait that Wolfgang painted was a generous one, according Lombroso the great merit of having shifted the focus of research from the abstract study of crime towards the concrete individuality of criminals. This had supposedly enabled the medical and biological sciences to make their contribution to this area of study with research that had begun to indicate the validity of some of his intuitions. To Wolfgang, Lombroso - who he claimed was intellectually honest, genuinely democratic and oriented more towards prevention than repression - probably seemed to be a secure point from which to try to mend the fracture that divided American criminology.

Wolfgang's essay was immediately translated and published in the Quaderni di Criminologia Clinica ("Notebooks of Clinical Criminology"), ${ }^{58}$ at a time when several organs of the Italian state were celebrating the international importance of Lombroso in an attempt to re-establish his credibility. Because there was no true anti-fascist purge after the Second World War, many of those who had been part of the regime had remained in office or soon returned. The police force of the Republic used such men and their fascist methods to repress ethnic minorities, homosexuality and prostitution, while the police scientific school that had taught public security cadres the principles of Lombroso's criminal anthropology throughout the fascist period was still in operation..$^{59}$ In the universities, academics who had worked during the dictatorship, often giving it open support, now held professorships: one of these was Benigno Di Tullio, a pupil of Ottolenghi who in 1931 had published a widely used handbook based on the congenital character theory of the habitual criminal and on the principle of eugenics. He founded the Italian Society of Criminology in 1957 and taught forensic psychopathology at the Sapienza University of Rome until his death in $1978 .{ }^{60}$

In this context, collaboration with the regime and the use by fascism of certain elements of criminal anthropology were obscured, as was the case in many other sectors. Specifically, these moves were aided by the esteem in which Carrara was held in the field of forensic medicine and, more generally, by the sympathy felt for the persecution that his family had suffered during the fascist years. In 1948 the city of Verona restored Lombroso's monument on the orders of an administration made up of the Christian Democratic Party, the Communist Party and the Socialist Party. ${ }^{61}$ In 1950, on the occasion of the first global conference of psychiatry, held in Paris, an exhibition on the history of psychiatric studies was staged, and Lombroso was among the few Italians who were remembered for having helped develop that field of knowledge. ${ }^{62}$

On the fiftieth anniversary of the Italian criminologist's death, two conferences were organised in Verona. One, attended by the Minister of Grace and Justice, was for legal experts and criminologists, while the theme of the other was psychopathological art. Additionally, there were two exhibitions of artwork by mentally ill artists and by prisoners. The minister, Guido Gonella, a Catholic and anti-fascist journalist, recalled the importance of Lombrosian thought, but criticised its materialist determinism. In reply Di Tullio, without mentioning what had happened during the dictatorship, said that many of Lombroso's ideas were only beginning to be put into practice. Finally, Cesare Lombroso's nephew, the lawyer Giulio Lombroso, who had been expelled during 
the fascist years and had worked on the repeal of the racial laws and sponsored the families of victims of the Nazi massacres, argued for the establishment of social services, the bio-psychiatric examination of children to combat juvenile delinquency, and a female police force. ${ }^{63}$

In the absence of true historiographical insights, and in the entanglement of real interests with opposing analyses, exaggeration, concealment and prejudice, the fracture that had occurred between criminologists confronted by fascism prevented the development of a unified interpretation of Lombroso. ${ }^{64}$ During the long debate that in those years led to the abolition of legalised prostitution, the anthropological theory of the born prostitute was repeatedly used by the socialist and anti-fascist senator Gaetano Pieraccini to argue against his party colleague and anti-fascist comrade, Lina Merlin, the great champion of the struggle for equal rights between men and women. ${ }^{65}$ Finally, in 1965, the University of Turin restored the professorship of criminal anthropology, to which Mario Portigliatti Barbos, a forty-year-old trained in forensic medicine, was appointed. ${ }^{66}$

\section{The 1970s: international rediscovery and critique}

In 1971 the publisher Einaudi brought out La maggioranza deviante ("The Deviant Majority") by Franco Basaglia, a psychiatrist experimenting with alternative therapies for the mentally ill. With his work in the psychiatric hospital of Gorizia, and with the publication of his writings and translations of other relevant authors, Basaglia succeeded in placing the issue of the reform of psychiatric support at the centre of the 1968 protests in Italy and in unleashing forces that ten years later brought about the closure of the country's psychiatric hospitals. ${ }^{67}$ La maggioranza deviante accused Italian psychiatrists of remaining in thrall to the ideas of Lombroso, of classifying psychopathic patients with a stigmatising intent, and of creating medical-social categories designed to isolate those whose behaviour disrupted the established order. For Basaglia, while that kind of psychiatry had been justified in the late nineteenth century it certainly was not acceptable in his day, for it aimed to defend social norms rather than treat illness. ${ }^{68}$

In the same year the Roman publisher Napoleone reprinted L'Uomo delinquente ("Criminal Man"), L'Uomo di genio ("The Man of Genius") and Gli Anarchici ("The Anarchists"). The publisher stated that the first volume, an abridged edition, was being reissued in order to bring to light texts "with racist and reactionary content." ${ }^{69}$ In the introduction to L'Uomo delinquente, Agostino Pirella, a psychiatrist closely linked to Basaglia, who in fact had taken part in a round table on the publishing initiative, described Lombroso as a "slave of the bourgeoisie" motivated by fascist anxieties and obsessions, and symbolic of the horrors of asylums. ${ }^{70}$ In his introduction to Gli Anarchici Franco Ferrarotti, the first holder of a chair of sociology in Italy, did not come to such Manichean conclusions and admitted, while still condemning the work, that Italian positivism had been liquidated by idealism before it had been able to rejuvenate Italian culture. Aligning himself with Ferrarotti, a young law historian named Mario Sbriccoli saw Lombroso as a father-ambiguous, contradictory and intentionally reactionary - of juridical socialism, a current of thought that had played an important role in the defence of freedom until the start of the twentieth century. ${ }^{71}$ 
41 The rediscovery of the anthropologist occurred almost simultaneously in several countries and from various perspectives. In a lecture given to the Collège de France on 12 February 1975, Michel Foucault outlined Lombroso's theory of political delinquency in order to explain the role played by psychiatry and psychology in response to the revolutionary wave unleashed in 1848 . By differentiating between legitimate national revolutions and illegitimate anarchist or socialist uprisings, the science had emerged as a bastion of order. ${ }^{72}$ On 19 March of the same year, Foucault spoke of the "racisme contre l'anormal" ("racism against the anormal") that had taken root in the institutions of the late nineteenth century with the shift from the juridical conception of criminality to the biopolitical understanding that the fascists and Nazis later applied to its most extreme consequences. ${ }^{73}$

42 At about the same time, the rediscovery of Lombroso in the USA took place in a variety of settings. Critiquing The Female Offender, which was published by Lombroso and Ferrero in Italian in 1893 and quickly translated into various languages, became a persistent convention of feminist thinking on criminality. The treatise was seen as the embodiment of a sexist ideology which, theorising the existence of a biologicallydefined female constitution, saw crimes committed by women primarily as acts against nature, and only secondarily as illegal actions. Associating themselves with the contemporary debate on criminology and sociology in the theoretical reflection on Marxism and feminism, in the early 1960s and mid-1980s scholars like Frances Heidensohn, Dorie Klein and Carol Smart equated The Female Offender - published in a new American edition in 1958 - with the archetypal misogynist mentality that later criminology had tried to hide while supporting all the stereotypes. ${ }^{74}$ "That originally sinful text," as Beverley Brown called it, was invaluable because it was so explicit that it could be used as the basis for a reconsideration of the legal system, the conditions of detention, criminal statistics and criminology. ${ }^{75}$ Feminist criminology also spread in Italy, thanks to the work of Tamar Pitch and Marina Graziosi, dovetailing with the pages that in 1981 Stephen Gould dedicated to Lombroso in his denunciation of the errors and prejudices of nineteenth-century anthropology and experimental psychology. ${ }^{76}$

43 In 1978, Georg Mosse, one of the most influential historians of the twentieth century, published his Toward the Final Solution. This book, which pieced together the origins of racism from the Enlightenment to the early twentieth century and gained an international readership, also referred to Lombroso as a thinker of crucial importance. A German Jew who moved to America after the rise of Nazism, Mosse did not believe that Lombroso was a racist, maintaining that as a liberal and then socialist Jew, the Italian had in fact supported the assimilation of the Jewish people. But his criminal anthropology had nevertheless given scientific legitimacy to those who, intertwining racism and eugenics, theorised the mass elimination of socially dangerous elements and made acceptable the idea of the extermination of the Jews. The biological conception of the born delinquent had thus contributed indirectly to the ideation of the Holocaust. ${ }^{77}$

Mosse's theory, vital to the international rediscovery of Lombroso and later reaffirmed in some ways by Daniel Pick, has been re-examined in subsequent studies. These have revealed how criminal anthropology spread within late nineteenth-century Germany, but they have also brought to light the extent to which his writings were criticised by German scientists. Furthermore, they exposed the tortuous course that led to the 
formulation of Nazi racism. ${ }^{78}$ Additionally, it has been observed how the theory of the reo nato was open to interpretations compatible with libertarian tendencies. ${ }^{79}$ Similar studies aimed at debunking overly teleological reconstructions have since been written on the genesis of fascist racism in Italy.$^{80}$ However, well before Mosse's book appeared, a direct link between criminal anthropology and another type of racism - that is, prejudice against Italians of the South - had already been identified in Italy.

In 1926, just before his arrest, Antonio Gramsci wrote an essay on the southern question that was first published four years later in Paris. In one passage, the then secretary of the Italian Communist Party underlined the part played by the positivist school of penal law in spreading among northern workers, via the Socialist Party, hostile prejudices against southerners by reinforcing pre-existing stereotypes with scientific authority. The bourgeois ideology that depicted the South as an encumbrance that impeded Italy's overall development justified the continuing exploitation of southern farmers by the agrarian-industrial bloc. In other words, it rationalised the pact made by northern businessmen and southern landowners. ${ }^{81}$ Included in the first edition of the Quaderni del carcere ("Prison Notebooks") of 1949, these reflections were reprinted several times before the critical edition of 1977. This contained accurate bibliographic records that revealed that Gramsci was familiar with Lombroso and saw him not only as a racist, but also as a bourgeois intellectual who had sought to stigmatise the leaders of subaltern classes as barbarous and pathological. ${ }^{82}$

In 1960 a young historian destined to have an important academic career replicated Gramsci's hypotheses. He was Massimo Salvadori who, in his Il mito del buongoverno ("The Myth of Good Government"), dedicated an entire chapter to the racism of Niceforo, Orano, Lombroso and Sergi, traces of which he believed could still be found in the image of the South circulating in northern Italy and abroad. ${ }^{83}$ The Gramscian link between positivist socialism and racism was allowed no space in later reconstructions of the history of the Italian Socialist Party, in which the membership of Lombroso and other intellectuals was seen as an important contribution to the debate and its irradiation among the middle classes.$^{84}$ However, the scholars of folklore, popular religiosity and the peasant culture of southern Italy returned time and again to the racist aspect of criminal anthropology, in a period in which ethnological research tended to stress the break from evolutionary anthropology. For Luigi Lombardi Satriani, "studying Lombroso means recognising the ideology of the Italian bourgeoisie of the late nineteenth century and early twentieth century, in its clear, less camouflaged form." ${ }^{85}$ But who was Lombroso? Lombardi Satriani concluded that he was "an ideologue masquerading as a scientist" who needed to be condemned universally despite the importance of the documents he had collected on the material culture of the subaltern classes. This was because a classist ideology still in force could be traced back to criminal anthropology. ${ }^{86}$

In 1973 Louis Maristany addressed the problem of the construction of the image of the criminal in Spain, in particular the political delinquent, through the reception of criminal anthropology, and two years later an anthology of texts by Lombroso was published in Spanish, along with an in-depth introduction. ${ }^{87}$ Finally, in 1978 George Becker saw Lombroso's theory of pathological genius as a pivotal part of the process of emphasising the irrational elements of genius which, beginning at the end of the eighteenth century, came to dominate the perception and self-perception of highly creative people until the mid-twentieth century. ${ }^{88}$ His study, predicated on a historical 
perspective, revived a debate on the character of creativity that in the following years would impact on the cognitive and educational sciences. ${ }^{89}$

In essence, Western culture rediscovered Lombroso in the militant climate of the 1970s, overcoming the exorcism carried out by the idealists and neo-thomists and recognising his centrality in a series of issues that went far beyond the internal debates of criminology. It was as if, all of a sudden, on the contemporary horizon a mountain appeared that was so high as to draw a shadow as far as the present, a mountain as yet almost entirely unknown.

\section{A period of exploration: 1975-1990}

It has been argued above that, in the years following the Second World War, and particularly during the early 1970s, Lombroso received highly authoritative criticism, of both a scientific and ethical-political nature, ${ }^{90}$ and yet it cannot be said that anyone developed an adequate historical understanding of the anthropologist, who by then had been elevated to the status of a polemical idol. In the absence of trustworthy studies, the exploration of his character, in all its complexity, was practically in its infancy. This was made clear by two works published in 1975: one was Giorgio Colombo's La scienza infelice, a book of photographs illustrating the state of abandonment into which Lombroso's museum had fallen due to the disinterest of the University of Turin. The other was a biography of Lombroso by Luigi Bulferetti, the first professional historian to dedicate a comprehensive work to the anthropologist. ${ }^{91}$

A scholar of the age of the Italian Risorgimento, Bulferetti also had a hand in the revival of interest in the history of Italian science and technology during the 1950s and 1960s. Nevertheless, it was precisely here that Bulferetti's biography fell most short. Although he identified the historicism of Giambattista Vico and the militant philosophy of Carlo Cattaneo as two of the main cultural influences on the young Lombroso - to be joined later by Darwinist psychology and anthropology - Bulferetti failed to grasp the implications of Lombrosian theories for the development of the human sciences. The author followed the biography written by Gina Lombroso, but without pointing out its excessive reverence and without making much use of the anthropologist's correspondence, which at this time was almost completely unstudied. Bulferetti ultimately saw Lombroso as a unification-era "conservative socialist", a philanthropist engaged in reforming the institutions of repression and control who had made some progress by diagnosing all forms of deviance as pathological conditions. ${ }^{92}$ While sharing other positivist assumptions, in particular those of gender differences, ${ }^{93}$ and glossing over the implicit risks of racism and its authoritarian derivatives ${ }^{94}$ the scholar produced a non-adversarial reconstruction of Lombroso's life. But while it had the virtue of anchoring its subject to historical fact, eschewing ideological projections and providing a great deal of accurate information, the book did not address the questions - other than some that were points of principle - most frequently raised by scholars. The biography, then, was a starting point for further research, but no more than that.

51 This is indeed how Bulferetti's biography was seen by one young researcher, Renzo Villa, who when reviewing it began a project on Lombroso on which he continued to work (albeit not in academia) until, in 1985, he achieved two important results. ${ }^{95}$ In that year Villa published Il deviante e $i$ suoi segni ("The Deviant and His Signs"), a history of 
criminal anthropology that he defined as an unsuccessful attempt to unify in a phenomenology of criminality the various categories under which nineteenth-century thought had conceptually integrated antisocial behaviours. Villa placed Lombroso's work in the context of the great transformation which, on the one hand, impacted on the penal system following the Enlightenment, the French and industrial revolutions and the establishment of the new social order, and, on the other, led to a new understanding of criminality through the agency of phrenology, psychiatry and anthropology. For Villa, the originality of criminal anthropology lay in its reception of the linguistics of Paolo Marzolo, the author of a semiology of the history of humanity, and in its adoption of an underdeveloped methodology that allowed Lombroso to absorb superficially the principal conceptualisations of his era without forcing him to take into account their contradictions and differences. Villa's interpretation marked an important shift away from Bulferetti's interpretation, because it placed Lombroso within the European debate that preceded him and traced his roots in comparative linguistics. Like glowing magma, a fluid stirred up by new movement, criminal anthropology never stabilised but burned itself out before Lombroso's death, having, however, made an indelible impression on the inner workings of the institutions of social order and defence. ${ }^{96}$

52 Villa's other achievement in 1985 came about through a collaboration with Portigliatti Barbos and Umberto Levra (an important scholar of the crisis of late nineteenthcentury Italy). The three mounted an exhibition in Turin which, using items from the museum of criminal anthropology, demonstrated its international importance as a permanent record of an early phase of the human sciences, of the systems of control and repression, and of the life of large marginal pockets of Italy during the industrial revolution. ${ }^{97}$

53 Against the background of a growing interest in Italian positivism and its different manifestations, as well as in the history of prisons and psychiatric hospitals, other scholars also turned their attention to Lombroso with a desire to understand rather than judge. In the context of a broader study of the part played by science in stigmatising certain social groups, José Luis Peset undertook research on Lombroso by investigating the spread of his theories in the Americas. ${ }^{98}$ Clara Gallini, an anthropologist and historian of religions, situated him at the head of the movement aimed at bringing the phenomena of magnetism and hypnotism back under the control of medical knowledge..$^{99}$ Lombrosian research on pellagra and the commitment to organising an embryonic form of social welfare were seen by Alberto De Bernardi as a response to the health emergency that adhered to the "class implications of political authority" but was also inspired by an agrarian reformism more advanced and modern than that existing in rural Italy. ${ }^{100}$ Luisa Mangoni identified him as a personality with the ability to influence Italian culture for two decades, enabling the social sciences to discard traditional approaches in favour of the more lively currents of European thought. ${ }^{101}$ Mary Gibson turned her attention to him when studying the criminalisation and control of prostitution, ${ }^{102}$ while a group of psychiatry historians from the University of Bologna, working on the stereotypes of difference and gender constructed by Italian positivists, saw La donna delinquente as a founding text of modern misogyny. ${ }^{103}$

Delfina Dolza, who as a member of the Lombroso family had access to its archives, wrote a biography of Paola and Gina. This painted them as two women who managed to 
overcome the rigid structures of their society and their father's prejudices concerning the mental capacity of women in order to become professional intellectuals. ${ }^{104}$ For others who studied the history of the female question, Lombroso had tried to transform the female body into a social one bound to traditional maternal duties and excluded from political and intellectual life. ${ }^{105}$ Nancy Harrowitz investigated the mechanisms of the production of stereotypes, taking the ruling classes' anxieties about legitimisation and integration as her starting point: anti-Semitism and misogyny could be results of the same process activated in a given cultural context brought about by social marginalisation (of Lombroso as a Jew, Matilde Serao as a woman). ${ }^{106}$

Even forensic medicine rediscovered Lombroso thanks to a book by Pier Luigi Baima Bollone. ${ }^{107}$ While Bruno Wanrooij and Nerina Milletti focused on the proto-sexology of Lombroso, there were those who investigated the absorption of Lombrosian theory into the criminology of other nations (Nicole Hahn Rafter, the USA; Laurent Mucchielli and others, France; Mariacarla Gadebush Bondio, Germany). ${ }^{108}$

In 1995 a large selection of fragments of Lombroso's writings were published in a volume titled Genio, delitto, follia. Scritti scelti, ("Genius, Crime, Madness. Selected Writings"). This provided a solution to the problem of access to minor sources and brought some order to the dense forest of his work by indicating three possible reading pathways. ${ }^{109}$ Mangoni advocated dividing Lombroso's work into three periods: the one when he was motivated by the country's needs following unification; that of his growing feeling of pessimism over the fate of the new state; and that of his criticism of the ruling classes and the turn to socialism. ${ }^{110}$ Ferruccio Giacanelli, a psychiatrist interested in the history of science, underlined Lombroso's contribution to the birth of psychiatry and psychology in Italy (in both their experimental and forensic medical forms) and placed his theory on pellagra in the context of scientific theories of the period. ${ }^{111}$ Delia Frigessi, a cultural historian, instead saw in the extension of the concept of atavism a general interpretative category developed in response to the emerging duality between the Italian north and south. ${ }^{112}$ In their reviews of the anthology, several authoritative commentators recognised that studying Lombroso meant reopening the debate on Italian positivism. ${ }^{113}$

\section{The explosion of research since 2000}

With the dawn of the new millennium, the historiography of Lombroso reached truly momentous dimensions, driven by interest in new research themes, particularly in the fields of the history of gender, sexuality, science and criminology. In parallel to this came the republication in English and Italian of the anthropologist's principal works and of some of his journalistic articles, as well as the publication of an expansive Italian-language bibliography of his output. ${ }^{114}$ The growing importance of neuroscience, however, has had less impact, since, while bringing increased interest in Lombroso of a superficial nature, it has not encouraged much genuine historical research. ${ }^{115}$

At the start of the 2000s, a romanticised biography filled with errors, but often mistaken for an authoritative source by unwary readers, ${ }^{116}$ met with a response by several important studies that may open new perspectives. Claudia Petraccone inserted Lombroso's thinking into the ongoing discussion on the process of nation-building and north-south dualism, which many scholars have worked on. ${ }^{117}$ In Cose da pazzi ("Crazy 
Things") Andrea Rondini told the story of the Lombroso school's influence on literary studies, in both the theoretical debate and the creative recycling of psychiatric and criminological theories by writers, a subject that has been taken up more recently by Alessio Berré. ${ }^{118}$ Emanuele D'Antonio has called attention back to Lombroso as a lay and assimilationist Jew, a defender of emancipation, Dreyfusist and, in his old age, even a Zionist. ${ }^{119}$ These studies have placed Lombroso in a more "lay" light, bringing to the fore the novelty of his ideas in the context of the Italian culture of his time. This tendency has continued, for instance with Pierpaolo Martucci's work on criminal anthropology's reading of white-collar crime, ${ }^{120}$ or the publication of extensive research by Damiano Palano on the birth of the psychology of the masses in Italy, a subject also studied by Olivier Bosc. ${ }^{121}$ The history of criminology returned with Born to Crime, in which Gibson - as previously mentioned - took a much wider look at the work of Lombroso's students, going beyond the dominant figure of Ferri and enlarging the field of investigation to include the fascist period. ${ }^{122}$

Gibson's conclusions were not entirely shared by Frigessi, who in 2003 published Cesare Lombroso. This was not a traditional biography like Bulferetti's but rather a vast and indepth review of the debates of the positivist period, in which Lombroso emerges as a great agitator of ideas, skilful provocateur, and talent spotter. ${ }^{123}$ Important answers emerged from these debates. These were often far removed from the positions from which the anthropologist had started but nonetheless were influenced by his thought up to the start of the twentieth century. For Frigessi, even Lombroso's personal journey was far from linear, having been loaded with libertarian and antimilitarist political significances in consequence of the change of direction he took in the early 1890 s. Mangoni and Martucci had already written about this turning point and Renato Girardi returned to it more recently when studying the contribution of Lombroso and his followers to the pacifist movement. ${ }^{124}$ Frigessi's work is the last great monograph dedicated to Lombroso, at least for now: agreeing with Villa and opposed to Gibson, the scholar has tended to downplay the contribution that Lombroso's ideas may have made to the repression of the fascist era. An earlier and opposing period, which evolved after 1876, is the focus of interest for Pietro Ficarra, who sees Lombroso as the chief exponent of the crisis of bourgeois progressivism in defiance of the early manifestations of the class struggle, to which the Italian elites responded with a topdown process of modernisation which had connotations of authoritarianism. ${ }^{125}$ The year 2003 also saw the publication of David Horn's study on the material culture of criminal anthropology: anthropometric equipment, judicial photographs, necroscopic investigations and experimental examinations provided "positive" and validating support for Lombroso's theories. ${ }^{126}$

60 The following year, in recreating the development of brain research, Michael Hagner placed Lombroso's theory of pathological genius in the contemporary historical context. This subject was also addressed by Paolo Mazzarello, Tobias Dahlkvist and Pierangelo Gentile. ${ }^{127}$ Daniele Velo Dalbrenta re-examined the Lombrosian proposition from the perspective of the philosophy of law, and the first conference on the theme was staged in Genoa under Bertrand Marquer's direction. ${ }^{128}$

61 This interest in the history of criminology has inevitably had an impact on the issue of Lombroso's reception in different national contexts, a subject that Neil Davie has studied in relation to Great Britain and Richard Wetzell for the German-speaking world. ${ }^{129}$ The latter, alongside Peter Becker, coordinated an international research group that 
has mapped out the spread of criminal anthropology in Argentina, Australia and Japan, as well as the countries already investigated. ${ }^{130}$ Through this effort, Lombroso's work has also been linked to the study of tattooing and the spread of eugenics, subjects which have also attracted the interest of Italian scholars. ${ }^{131}$ As the more recent summaries of the history of criminology have reiterated the founding role of Lombroso, the research has expanded, extending to Russia and Scandinavia. ${ }^{132}$

Apart from the history of criminology and the penal system, on which the debate is very much alive, ${ }^{133}$ it is difficult to think of any intense research endeavour on the highly varied aspects of Lombroso's work that can be traced back to a unitary interpretation. These aspects range from the history of sexuality, of sexology and of homosexuality ${ }^{134}$ to that of terrorism, ${ }^{135}$ and from research on the origins of asylum $\operatorname{art}^{136}$ to that of the female question, and from the history of childhood ${ }^{137}$ to the material and visual history of science. ${ }^{138}$

In addition to all the above, in 2009, after major restoration and refurbishment, the University of Turin reopened the Museum of Criminal Anthropology as part of a project aimed at making scientific collections of historical interest available to the public. The material culture of criminal anthropology and its documentary legacy - photographs, tattoos, scientific instruments, biological specimens, artistic creations, portraits, autobiographical writings - have all undergone systematic research that made it possible to publish a museum catalogue, which was updated in 2015 after further research. ${ }^{139}$

Planning the museum led to the publication of Cesare Lombroso cento anni dopo ("Cesare Lombroso One-Hundred Years Later"), which gives an overview of the many studies currently being undertaken on Lombroso's work and legacy. ${ }^{140}$ For much the same reason, Paul Knepper and Per Ystehede produced The Cesare Lombroso Handbook. ${ }^{141}$ As with Cento anni dopo, this study has underlined the central role played by Lombroso's work in founding a new field of knowledge that developed with the international circulation and discussion of his ideas. Collaborative works have also resulted from two conferences held in Verona and Turin to mark the centenary of Lombroso's death. ${ }^{142}$ Finally, in 2017 the city adopted by Lombroso hosted a conference on the relationship between him and contemporary French culture. The opening of the museum, while provoking outrage on the part of neo-Bourbon movements, ${ }^{143}$ has also given rise to a new phase of studies that is currently under way thanks to the valuable body of documents that Lombroso's descendants donated to the University of Turin. The Lombroso Museum undertook an effort to catalogue, register and digitalise both this donation and papers kept by other organisations, and thus over 2,600 original documents - mostly letters addressed to or written by Lombroso from 1851 to 1909 have been available online since July $2018 .{ }^{144}$

\section{Conclusion}

65 It has been argued that, after an initial period in which Lombroso and his closest collaborators worked to establish a hagiographic historical account that depicted him as the father of criminology, outside of Italy and the United States the memory of the anthropologist gradually faded in significance. In Italy, the fascist attitude towards Lombroso was ambiguous: on the one hand the regime adopted some of the measures 
suggested by the positivist criminologist, but on the other it saw the anthropologist, due to his status as a free thinker, socialist and Jew, as an inconvenient figure.

In the same period, the Chicago school set out an interpretation of criminal and deviant phenomena that was radically different to the one proposed by Lombroso, who nevertheless continued to have a following in American universities and institutions. The contrast between these two schools of thought motivated the work of Lindesmith and Levin, whose essay can be considered the first attempt to rethink Lombroso's role from a historiographical perspective unburdened by any need to lionise his contribution.

67 A sense of celebration returned fleetingly after the Second World War on the occasion of the fiftieth anniversary of Lombroso's death, when many of those who had collaborated with the fascist regime still had roles in Italian institutions. The most important study to appear in those years, which were characterised by Lombroso's general slip into oblivion, was that of the American Marvin Wolfgang, who attempted to find a balance between the biological and sociological interpretations of criminality, underlining the multi-factoral nature of Lombroso's research and thus arguing for his central position.

If up to then the memory of Lombroso had been kept alive and discussed primary in the context of studies from the fields of criminology and medical forensics, the 1970s brought a sea change. In the decade's climate of militant political engagement, the racist, misogynist and reactionary aspects of his ideas were used by intellectuals of the highest order - such as Basaglia, Foucault, Gould, Heidensohn, Mosse and Smart - to trace back to positivist criminology some of the scientific roots of totalitarian thought and of male domination. The 1970s also saw the publication of the first real biography of Lombroso, written by Luigi Bulferetti, which however failed to respond to the new international interest in the figure. The new questions regarding the significance of Lombroso's work brought responses from a series of works published in the 1980s and 1990s, of which the most important were the monograph by Renzo Villa and an exhibition held in Turin in 1985.

The 2000s have seen the continuation of this research, above all thanks to the books by Gibson and Frigessi, as well as the republication of many of Lombroso's texts, the appearance of a remarkable number of minor studies and of frequent references to Lombroso in the context of research into the history of sexuality, homosexuality, the southern Italian question, racism, and the relations between art and scientific ideas.

Far from having been forgotten, Lombroso still divides, provokes and raises passionate hostility, as is demonstrated by the social media accounts managed by the neo-Bourbon movements. The judgement on Lombroso has been the subject of strongly opposing views: this is partly the result of his own writings, and partly the simple consequence of the issues that he focused on during the course of his research, issues that invited perspectives that have changed radically during the course of the century and a half that will soon separate us from the first edition of Uomo delinquente ("Criminal Man"). The continuous oscillations between criminological theories often end up finding in this character a symbol on which to clash and, in the end, these tensions are the result of a tendency to project the ideas of the present onto the past. Seen as an intellectual hate figure by some, an ideologist disguised as a scientist by others, and a model of scientific elusiveness by yet others, Lombroso retains his place at the origins of the human sciences, from which he admonishes us about our past. 


\section{BIBLIOGRAPHY}

Ai giovani, Avanti!, 21 October 1909.

Antonini, G., I precursori di C. Lombroso, Turin, Bocca, 1900.

Aramini, A., Bovo, E. (Eds.), La pensée de la race en Italie. Du romantisme au fascisme, Besançon, Presses universitaires de Franche-Comté, 2018.

Asor Rosa, A., La cultura, Storia d'Italia, vol. IV, Dall'unità a oggi, II, Turin, Einaudi, 1975.

Aschaffenburg, G., Crime And Its Repression, Boston, Little, Brown and Company, 1913.

Babini, V.P., Minuz, F., Tagliavini, A., La donna nelle scienze dell'uomo, Milan, Angeli, 1986.

Babini, V.P., In the Name of Father. Gina and Cesare Lombroso, in Babini, V., Simili, R. (Eds.), More than Pupils. Italian Women in Science at the Turn of the 20th Century, Florence, Olschki, 2007.

Babini, V.P., Liberi tutti. Manicomi e psichiatri in Italia: una storia del Novecento, Bologna, il Mulino, 2009.

Baima Bollone, P.L., Cesare Lombroso ovvero il principio dell'irresponsabilità, Turin, Sei, 1992.

Baima Bollone, P.L., Opere di Cesare Lombroso in lingua italiana, Turin, Università Popolare di Torino Editore, 2017.

Basaglia, F., Ongaro Basaglia, F., La maggioranza deviante, Torino, Einaudi, 1971.

Beccalossi, C., Female Sexual Inversion. Some-Sex Desires in Italian and British Sexology, c. 1870-1920, Basingstoke, Palgrave Macmillan, 2012.

Beccalossi, C., Madness and Sexual Psychopathies as the Magnifying Glass of the Normal: Italian Psychiatry and Sexuality, c. 1880-1910, Social History of Medicine, 2013, 27.

Becker, G., The Mad Genius Controversy. A Study in the Sociology of Deviance, Beverly Hills, Calif., Sage Publications, 1978.

Becker, P., Lombroso come «luogo della memoria» della criminologia, in Montaldo, S. (Ed.), Cesare Lombroso. Gli scienziati e la nuova Italia, Bologna, il Mulino, 2010.

Bellassai, S., La legge del desiderio. Il progetto Merlin e l'Italia degli anni Cinquanta, Rome, Carocci, 2006.

Benadusi, L., Il nemico dell'uomo nuovo. L'omosessualità nell'esperimento totalitario fascista, Milan, Feltrinelli, 2005.

Berré, A., Nemico della società. La figura del delinquente nella cultura letteraria e scientifica dell'Italia postunitaria, Bologna, Pendragon, 2015.

Bonger, W.A., Criminalité et conditions économiques, Amsterdam, G.P. Tierie, 1905.

Bonger, W.A., An Introduction to Criminology, London, Methuen \& Co., 1937.

Bosc, O., La foule criminelle. Politique et criminalité dans l'Europe du tournant du XIX ${ }^{e}$ siècle, Paris, Fayard, 2007.

Brown, B., Women and Crime. The dark figures of criminology, Economy and Society, 1986, 15, p. 355-352.

Bulferetti, L., Cesare Lombroso, Turin, Utet, 1975. 
Butler, R.R., Jones, R.S., del Carmen A., Cesare Lombroso: The Father of Criminology Redifined, Dubuque, Kendall Hunt, 2018.

Calafato, T., The similarities between Lombroso's theories on political crime and contemporary terrorism issues, Behavioral Sciences of Terrorism and Political Aggression, 2017, 9.

Caplan, J., "One of the Strangest Relics of a Former State": Tatoos and the Discourses of Criminality in Europe, in Becker, P., Wetzell, R.F., (Eds.), Criminals and Their Scientists. The History of Criminology in International Perspective, Cambridge, Cambridge University Press, 2006.

Ca [Carrara, M.], Antropologia criminale, in Enciclopedia italiana di scienze, lettere ed arti, Rome, Treccani, 1929.

Carrara, M., L'Antropologia Criminale e la "Analogia" nel diritto penale. Il Crepuscolo dei Codici?, Archivio di Antropologia criminale, psichiatria e medicina legale fondato da Cesare Lombroso per servire allo studio dell'uomo alienato e delinquente (AP), 1934, LIV.

Carrara, M., Romanese, R., Canuto, G., Tovo, C., Manuale di Medicina legale, Turin, Utet, 1937.

Cassata, F., Molti, sani e forti. L'eugenetica in Italia, Turin, Bollati Boringhieri, 2006.

Chan, D.W., The Mad Genius Controversy. Does the East Differ from the West? Education Journal, 2001, 29 .

Colombo, G., La scienza infelice. Il museo di antropologia criminale di Cesare Lombroso, Turin, P. Boringhieri, 1975.

Come Lombroso intendeva il socialismo, Avanti!, 21 October 1909.

Commemorazione di C. Lombroso, Il Lavoro, 21 October 1909.

Comptes-rendus du VI ${ }^{\mathrm{e}}$ Congrès International d'Anthropologie Criminelle (Turin, 28 avril- 3 mai 1906), Turin, Bocca, 1908.

La conferenza di Padre Gemelli interrotta coi clamori e coi fischi al Teatro Balbo di Torino, La Stampa, 22 February 1910.

Croce, B., Storia d'Italia dal 1871 al 1915, Bari, Laterza, 1928.

Dahlkvist, T., The Epileptic Genius: The Use of Dostoevsky as Exemple in the Medical Debate over the Pathology of Genius, Journal of the History of Ideas, 2015, 76.

D’Antonio, E., Aspetti della rigenerazione ebraica e del sionismo in Cesare Lombroso, Società e Storia, 2001, 92, p. 282-309.

Davie, N., Tracing the criminal: the rise of scientific criminology in Britain, 1860-1918, Oxford, The Bardwell Press, 2005.

De Bernardi, A., Il male della rosa. Denutrizione e pellagra nelle campagne italiane fra ' 800 e ' 900 , Milano, Angeli, 1984.

DeLisi, M., Revisiting Lombroso, in Cullen, F., Wilcox, P. (Eds.), The Oxford Handbook of Criminological Theory, Oxford University Press, Oxford, 2013, p. 5-21.

Dickie, J., Darkest Italy. The Nation and Stereotypes of the Mezzogiorno, 1860-1900, Basingstoke, Palgrave Macmillan, 1999.

Diemoz, E., A morte il tiranno. Anarchia e violenza da Crispi a Mussolini, Turin, Einaudi, 2011.

Dolza, D., Essere figlie di Lombroso. Due donne intellettuali tra ‘ 800 e ‘900, Milan, Franco Angeli, 1991. 
Dunnage, J., The legacy of Cesare Lombroso and criminal anthropology in the post-war Italian police: a study of the culture, narrative and memory of a post-fascist institution, Journal of Modern Italian Studies, 2017, 22.

Ferri, E., Cesare Lombroso, Nuova Antologia, 1 November 1909.

Ficarra, P., La modernizzazione in Italia e Lombroso. la svolta autoritaria del progresso (1876-1882), Rome, Edizioni di Storia e Letteratura, 2016.

Fijnaut, C., Criminology and the Criminal Justice System. A Historical and Transatlantic Introduction, Cambridge, Intersentia, 2017.

Finzi, R., Il pregiudizio. Ebrei e questione ebraica in Marx, Lombroso e Croce, Milan, Bompiani, 2011.

Foot, J., La repubblica dei matti. Franco Basaglia e la psichiatria radicale in Italia, 1961-1978, Milan, Feltrinelli, 2014.

Forti Lombroso, S., Si può stampare. Pagine vissute 1938-1945, Rome, Casa Editrice Dalmatia, 1945.

Forti Lombroso, S., Case di sogno, case di mattoni, Genoa, Sagep, 1969.

Foucault, M., Les anormaux. Cours au collège de France. 1974-1975, Paris, Gallimard-Seuil, 1999.

Franco, G.G., Pickman e Lombroso a Torino ossia l'ipnotismo chiaroveggente, La Civiltà Cattolica (CC) $1890,41$.

Franco, G.G., Indole degli agenti dello spiritismo, CC, 1893, 44.

Frigessi, D., La scienza della devianza, in Frigessi, D., Giacanelli, F., Mangoni, L. (Eds), Cesare

Lombroso. Genio, delitto, follia. Scritti scelti, Turin, Bollati Boringhieri, 1995.

Frigessi, D., Cesare Lombroso, Turin, Einaudi, 2003.

G.C., Un altro grande! Cesare Lombroso, Il Grido del Popolo, 20 October 1909.

Gadebush Bondio, M.C., Die Rezeption der Kriminal-anthropologischen Theorien von Cesare Lombroso in Deutschland von 1880-1914, Husum, Matthiesen, 1995.

Gadebush Bondio, M.C., La Germania e i paesi di lingua tedesca, in Montaldo, S., Tappero, P. (Eds.), Cesare Lombroso cento anni dopo, Turin, Utet, 2009.

Gallini, C., La sonnambula meravigliosa. Magnetismo e ipnotismo nell'Ottocento italiano, Milan, Feltrinelli, 1983.

Garfinkel, P., Criminal Law in Liberal and Fascist Italy, Cambridge, Cambridge University Press, 2016.

Garin, E., La dignità del deviante, Il Sole 24 ore, 29 October 1995, 289.

Garton, S., Crime, Prisons, and Psychiatry: Reconsidering Problem Populations in Australia, 1890-1930, in Becker, P., Wetzell, R.F., (Eds.), Criminals and Their Scientists. The History of Criminology in International Perspective, Cambridge, Cambridge University Press, 2006.

Gemelli, A., I funerali di un uomo e di una dottrina: in morte di Cesare Lombroso, Monza, Tipografia degli Artigianelli, 1910.

Gentile, G., La filosofia in Italia dopo il 1850. III. I positivisti. VI. Cesare Lombroso e la scuola italiana di antropologia criminale, La Critica, 1909, 7.

Gentile P., L'anomalia Verdi, ovvero la resa del professore: il pensiero di Cesare Lombroso sulla musica, Laboratoire italien, 2017, 20.

Gerbi, S., I Cosattini. Una famiglia antifascista di Udine, Milan, Hoepli, 2016. 
Germinario, F., Fascismo e antisemitismo. Progetto razziale e ideologia totalitaria, Rome-Bari, Laterza, 2009.

Giacanelli, F., Il medico, l'alienista, in Frigessi, D., Giacanelli, F., Mangoni, L. (Eds), Cesare Lombroso. Genio, delitto, follia. Scritti scelti, Turin, Bollati Boringhieri, 1995.

Gibson, M., Prostitution and the State in Italy: 1860-1915, New Brunswick and London, Rutgers University Press, 1986.

Gibson, M., On the Insensitivity of Women. Science and the Woman Question in Liberal Italy, 1890-1910, Journal of Women's History, 1990, $2 / 2$.

Gibson, M., Biology or Environment? Race and Southern "Deviancy" in the Writings of Italian Criminologists, 1880-1920, in Schneider, J. (Ed.), Italy's “Southern Question": Orientalism in One Country, New York, Berg, 1998.

Gibson, M., Born to Crime. Cesare Lombroso and the Origins of Biological Criminology, Westport and London, Praeger, 2002.

Girardi, R., Né pazzi né sognatori. Il pacifismo democratico italiano tra Otto e Novecento, Pisa, Pacini, 2016.

I giudizi di Padre Gemelli sull'opera lombrosiana, La Stampa, 11 December 1909.

Goetz, H., Il giuramento rifiutato. I docenti universitari e il regime fascista, Milan, La Nuova Italia, 2000.

Goring, C.B., The English Convict. A Statistical Study, London, Darling and Son, 1913.

Gould, S.J., The Mismeasure of Man, New York, W.W. Norton \& Company, 1981.

Govoni, P., Professionalizzazione dello scienziato e ingresso delle donne nella scienza accademica. I casi inglese e italiano a confronto, in Montaldo, S. (Ed.), Cesare Lombroso. Gli scienziati e la nuova Italia, Bologna, il Mulino, 2010.

Gramsci, A., Alcuni temi della questione meridionale, n.p, n.d. [1930].

Gramsci, A., Quaderni del carcere. Edizione critica dell'Istituto Gramsci, Turin, Einaudi, 1977, III.

Granieri, E., Fazio, P., The Lombrosian Prejudice in Medicine. The Case of Epilepsy. Epileptic Psychosis. Epilepsy and Aggressiveness, History of Neurology, 2012, 33, p. 173-192.

Guarnieri, L., L'atlante criminale. Vita scriteriata di Cesare Lombroso, Milan, Mondadori, 2000.

Guarnieri, P., Un piccolo essere perverso. Il bambino nella cultura scientifica italiana tra Otto e Novecento, Contemporanea, 2006, 2, p. 253-284.

Guarnieri, P., Caesar or Cesare? American and Italian images of Lombroso, in Knepper, P., Ystehede, P.J. (Eds), The Cesare Lombroso Handbook, Routledge, Abingdon, 2013.

Hagner, M., Geniale Gehirne. Zur Geshichte der Elitegehirnforschung, Göttingen, Wallstein, 2004.

Heidensohn, F., The Deviance of Women: A Critique and a Enquiry, The British Journal of Sociology, $1968,19 / 2$.

Harrowitz, N.A., Antisemitism, Misoginy and the Logic of Cultural Difference. Cesare Lombroso and Matilde Serao, Lincoln (NE) and London, University of Nebraska Press, 1994.

Hooton, E., The American Criminal. An Anthropological Study, v.1, The Native and White Criminal of Native Parentage, Harvard, Harvard University Press, 1939. 
Horn, D., This Norm Which Is Not One. Reading the Female Body in Lombroso's Anthropology, in Terry, J., Urla, J. (Eds.), Deviant Bodies: Critical Perspectives on Difference in Science and Popular Culture, Bloomington, Indiana University Press, 1995.

Horn, D., The criminal body. Lombroso and the anatomy of deviance, London, Routledge, 2003.

Horton, D.M., Rich, K.E., The Criminal Anthropological Writings of Cesare Lombroso Published in the English Language Periodical Literature During the Late 19th and Early 20th Centuries, Lewiston, Edwin Mellen Press, 2004.

Israel, G., Nastasi, P., Scienza e razza nell'Italia fascista, Bolonga, il Mulino, 1998.

Knepper, P., Ystehede, P.J., The Cesare Lombroso Handbook, London and New York, Routledge, 2013.

Kurella, H., Lombroso als Mensch und Forscher, Wiesbaden, Bergmann, 1910.

Kurella, H., Cesare Lombroso. A Modern Man of Science, London and New York, Rebman, 1911.

La salma di Lombroso a Verona, Avanti!, 24 October 1909.

Lindesmith, A., Levin, Y., The Lombrosian Myth in Criminology, American Journal of sociology, 1937, 42.

Levra, U. (Ed.), La scienza e la colpa. Crimini, criminali, criminologi: un volto dell'Ottocento, Milan, Electa, 1985.

Lombardi Satriani, L.M., Menzogna e verità nella cultura contadina del Sud, Naples, Guida, 1974.

Lombardi Satriani, L.M., Lombroso scienziato razzista, Storia illustrata, 1978, 252.

Lombroso, C., My Museum of Criminal Psychology, The New York Times, 17 February 1907a.

Lombroso, C., Come nacque e come crebbe l'antropologia criminale, in Ricerche di psichiatria e nevrologia, antropologia e filosofia dedicate al Prof. Enrico Morselli nel XXV anno del suo insegnamento universitario, Milan, Vallardi, 1907b, p. 501-510.

Lombroso, C., Introduction, in Criminal Man According To The Classification Of Cesare Lombroso Briefly Summarised By His Doughter. With An Introduction By Cesare Lombroso, New York and London, G.P. Putnam's Sons, 1911, p. XI.

Lombroso, C., L’Uomo delinquente, Rome, Napoleone, 1971.

Lombroso, C, Genio, delitto, follia. Scritti scelti, Turin, Bollati Boringhieri, 1995.

Lombroso, C., In Calabria, Locri, Franco Pancallo Editore, 2008.

Lombroso, C., Ricerche sui fenomeni ipnotici e spiritici. Con un saggio introduttivo di Giorgio Colombo, Milan, et al./edizioni, 2010.

Lombroso, C., L'uomo delinquente. Quinta edizione - 1897. Presentazione di Armando Torno, Milan, Bompiani, 2013.

Lombroso, C., Ferrero, G., La donna delinquente, la prostituta e la donna normale. Prefazione di Mary Gibson e Nicole Hahn Rafter, Milan, et al./edizioni, 2009.

Lombroso, G., I vantaggi della degenerazione, Turin, Bocca, 1904.

Lombroso, G., Cesare Lombroso. Storia della vita e delle opere narrata dalla figlia, Turin, Bocca, 1915.

Lombroso Ferrero, G., Cesare Lombroso. Storia della vita e delle opere. Seconda edizione, Bologna, Zanichelli, 1921.

Lombroso G., Vita di Lombroso, Milan, Istituto italiano per il libro del popolo, 1924. 
Lombroso, G., Vida de Lombroso. Presentacion por Luis Jimenez de Asua, Buenos Aires, Aquiles Gatti, 1940.

Lombroso, P., Lombroso, G., Cesare Lombroso. Appunti sulla vita. Le opere, Turin, Bocca, 1906.

Lombroso, U., Nel centenario della nascita di mio padre, L'illustrazione del medico, 1935, n.p, n.d.

Lindesmith, A., Levin, Y., The Lombrosian Myth in Criminology, American Journal of Sociology, 1937, 42, p. 653-671.

Lottin, J., Quetelet. Staticien et Sociologue, Louvain, Institut Supérieur de Philosophie, Paris, Alcan, 1912.

Maggiore, G., Logica e moralità del razzismo, La difesa della razza, 5 September 1938.

Mangoni, L., Una crisi di fine secolo. La cultura italiana e la Francia fra Otto e Novecento, Turin, Einaudi, 1985.

Mangoni, L., Eziologia di una nazione, in Frigessi, D., Giacanelli, F., Mangoni, L. (Eds), Cesare Lombroso. Genio, delitto, follia. Scritti scelti, Turin, Bollati Boringhieri, 1995.

Mannheim, H., Lombroso and His Place in Modern Criminology, The Sociological Review, 1936, 28.

Mantovani, C., Rigenerare la società. L'eugenetica in Italia dalle origini ottocentesche agli anni Trenta, Soveria Mannelli, Rubettino, 2004

Marchetti, P. Le "sentinelle del male". L'invenzione ottocentesca del criminale nemico della società tra naturalismo giuridico e normativismo psichiatrico, Quaderni fiorentini per la storia del pensiero giuridico moderno, 2009, 38.

Maristany, L., El gabinete del doctor Lombroso (Delinquencia y fin de siglo en España), Barcelona, Cuadernos Anagrama, 1973.

Marro, A., Precursori e primordi dell'antropologia criminale, in L'opera di Cesare Lombroso nella scienza e nelle sue applicazioni. Nuova edizione con introduzione del Prof. Cesare Lombroso ed un'appendice bibliografica, Turin, Bocca, 1908.

Martucci, P., Le piaghe d'Italia. I lombrosiani e i grandi crimini economici nell'Europa di fine Ottocento, Milan, Angeli, 2002.

Mazzarello, P., Il genio e l'alienista. La strana visita di Lombroso a Tolstoj, Turin, Bollati Boringhieri, 2005.

Michels, R., Cesare Lombroso. Note sull'uomo politico e sull'uomo privato (Pel Congresso di Colonia, ottobre 1911), AP, 1911, XXXII.

Milicia, M.T., Lombroso e il brigante. Storia di un cranio conteso, Rome, Salerno Editore, 2014.

Milletti, N., Analoghe sconcezze. Tribadi, saffiste, invertite ed omosessuali: categorie e sistemi sesso/genere nella rivista di antropologia criminale fondata da Cesare Lombroso (1880-1949), DWF donnawomanfemme, 1994, 4.

Mogilner, M., Homo Imperii. A History of Physical Anthropology in Russia, Lincoln (NE) and London, University of Nebraska Press, 2013.

Monachesi, E., Trends in Criminological Research in Italy, American Sociological Review, 1936, 1.

Montaldo, S. (Ed.), Cesare Lombroso. Gli scienziati e la nuova Italia, Bologna, il Mulino, 2010.

Montaldo, S. (Ed.), Il Museo di Antropologia criminale Cesare Lombroso dell'Università di Torino. In collaborazione con Cristina Cilli, Cinisello Balsamo, Silvana Editoriale, 2015. 
Montaldo, S., The Relics of Two 19th-Century Scientists. Carlo Giacomini and Cesare Lombroso, in Beretta, M., Conforti, M., Mazzarello, P. (Eds.), Savant Relics. Brains and Remains of Scientists, Sagamore Beach, MA, Watson Publishing International, 2016.

Montaldo, S., L'antropologia criminale e l'esercito italiano (1884-1920), in Brizzi, G.P., Signori, E. (Eds.), Minerva armata. Le università e la Grande guerra, Bologna, Clueb, 2017.

Montaldo, S., Eugenica “latina"? Criminologia e sterilizzazioni femminili nell'Italia di fine '800, Passato e Presente, 2018, 104, p. 19-43.

Montaldo, S., Tappero, P. (Eds.), Cesare Lombroso cento anni dopo, Turin, Utet, 2009.

Morehead, A., The "Musée de la folie". Collecting and exhibiting "chez les fous", Journal of the History of Collections, 2011, 23.

Morselli, E., Cesare Lombroso e l'antropologia generale, in L'opera di Cesare Lombroso nella scienza e nelle sue applicazioni. Nuova edizione con introduzione del Prof. Cesare Lombroso ed un'appendice bibliografica, Turin, Bocca, 1908.

Mosse, G.L., Toward the Final Solution. A History of European Racism, New York, Howard Fertig Inc., 1978.

Mucchielli, L. (Ed.), Histoire de la criminologie française, Paris, L'Harmattan, 1994.

Mucchielli, L., Criminology, Hygienism, and Eugenics in France, 1870-1914: The Medical Debates on the Elimination of "Incorrigible", in Becker, P., Wetzell, R.F., (Eds.), Criminals and Their Scientists. The History of Criminology in International Perspective, Cambridge, Cambridge University Press, 2006.

Musumeci, E., Cesare Lombroso e le neuroscienze: un parricidio mancato. Devianza, libero arbitrio, imputabilità tra antiche chimere ed inediti scenari, Milan, Angeli, 2012.

Nakatami, Y., The Birth of Criminology in Modern Japan, in Becker, P., Wetzell, R.F., (Eds.), Criminals and Their Scientists. The History of Criminology in International Perspective, Cambridge, Cambridge University Press, 2006.

Nani, M., Ai confini della nazione. Stampa e razzismo nell'Italia di fine Ottocento, Rome, Carocci, 2006.

Nicolosi, R., Hartmann, A. (Eds.), Born to Be Criminal. The Discourse of Criminality and the Practice of Punishment in Late Imperial Russia and Early Soviet Union. Interdisciplinary Approaches, Bielefeld, Transcript Verlag, 2017.

L'opera di Cesare Lombroso giudicata dal dott. Agostino Gemelli, Il Momento, 23 October 1909. Orano, P., Dopo la morte di Cesare Lombroso. L'opera del maestro, Avanti!, 21 October 1909. Palano, D., Il potere della moltitudine. L'invenzione dell'inconscio collettivo nella teoria politica e nelle scienze sociali italiane tra Otto e Novecento, Milan, V\&P, 2002.

Palano, D., Cesare Lombroso. Scritti per il «Corriere» 1884-1908, Milan, Fondazione Corriere della Sera, 2014.

Papa, E.R., Storia di due manifesti. Il fascismo e la cultura italiana, Milan, Feltrinelli, 1958.

Papini, G., Prezzolini, G., La coltura italiana, Florence, Lumachi, 1906.

Parsons, P.A., Crime and the Criminal. An Introduction to Criminology, New York and London, Alfred A. Knopf, 1926.

Peset, J.L, Ciencia y marginación. Sobre negros, locos y criminals, Barcelona, Critica, 1983. 
Peset, J.L, Peset, M. (Eds), Lombroso y la escuela positivista italiana. Estudio preliminar, Madrid, Istituto Arnau de Vilanova, 1975.

Petit, C., Lombroso en Chicago. Presencias Europeas en la Modern Criminal Science Americana, Quaderni fiorentini per la storia del pensiero giuridico moderno, 2007, 36/II, p. 801-900.

Petraccone, C., Le due civiltà. Settentrionali e meridionali nella storia d'Italia, Rome-Bari, Laterza, 2000.

Petrizzo, A., Pelli criminali? La scuola lombrosiana e il corpo tatuato a fine Ottocento, Contemporanea, 2016, 1, p. 16-23.

Picotti, L, Zanuso, F. (Eds), L'antropologia criminale di Cesare Lombroso: dall'Ottocento al dibattito filosofico-penale contemporaneo, Rome and Naples, ESI, 2011.

Pick, D., Faces of Degeneration. A European Disorder, c. 1848 - c. 1918, Cambridge, Cambridge University Press, 1993 [I ${ }^{\text {a }}$ edizione 1989].

Pirella, A., Prefazione, in Lombroso, C. (Ed.), L'uomo di genio, Rome, Napoleone, 1971.

Pogliano, C., Il periodico ritorno di Lombroso, Belfagor, 1996, 51.

Il pregiudizio anticlericale in Italia, CC, 1906, 57.

Rafter, N.H, Criminal Anthropology in the United States, Criminology, 1992, 30, p. 525-546.

Rafter, N.H., Gibson, M. (Eds.), Criminal Woman, the Prostitute and the Normal Woman by Cesare Lombroso and Guglielmo Ferrero, Duke University Press, 2006.

Rafter, N.H., Gibson, M. (Eds.), Cesare Lombroso. Criminal Man, Durham, Duke University Press, 2006.

Rafter, N.H., The Criminal Brain. Undestanding Biological Theories of Crime, New York, New York University Press, 2008.

Rafter, N.H., Gli Stati Uniti, in Montaldo, S., Tappero, P. (Eds.), Cesare Lombroso cento anni dopo, Turin, Utet, 2009.

Rafter, N.H., Le teorie biologiche sul crimine negli Stati Uniti da Lombroso a oggi, in Montaldo, S., Tappero, P. (Eds.), Cesare Lombroso cento anni dopo, Turin, Utet, 2009.

Raine, A., The Anatomy of Violence. The Biological Roots of Crime, New York, Pantheon Books, 2013.

Rock, P., Cesare Lombroso as a signal criminologist, Criminology \& Criminal Justice, 2007, 7/2.

Rodler, L. (Ed.), Cesare Lombroso. L'Uomo delinquente studiato in rapporto all'antropologia, alla medicina legale ed alle discipline carcerarie, Bologna, il Mulino, 2011.

Rodler, L. (Ed.), Cesare Lombroso. L'uomo bianco e l'uomo di colore. Letture sull'origine e la varietà delle razze umane, Bologna, Archetipolibri, 2012.

Rondini, A., Cose da pazzi. Cesare Lombroso e la letteratura italiana, Pisa and Roma, Istituti editoriali e poligrafici internazionali, 2001.

Saldana, Q., The New Criminal Anthropology, Journal of Criminal Law and Criminology, 1933, 24.

Salis Seewis, F., Civiltà moderna, scienza e malfattori, CC, 1892, 43.

Salomoni, A., La Russia, in Montaldo, S., Tappero, P. (Eds.), Cesare Lombroso cento anni dopo, Turin, Utet, 2009.

Salvadori, M.L., Il mito del buongoverno. La questione meridionale da Cavour a Gramsci, Torino, Einaudi, 1981 [first edition 1960]. 
Salvatore, R.D, Positivist Criminology and State Formation in Modern Argentina, 1890-1940, in Becker, P., Wetzell, R.F., (Eds.), Criminals and Their Scientists. The History of Criminology in International Perspective, Cambridge, Cambridge University Press, 2006.

Sbriccoli, M., Dissenso politico e diritto penale in Italia tra Otto e Novecento. Il problema dei reati politici dal Programma di Carrara al Trattato di Manzini, Quaderni fiorentini per la storia del pensiero giuridico moderno, 1973, 2, p. 607-702.

Sbriccoli, M., Il diritto penale sociale (1883-1912), Quaderni fiorentini per la storia del pensiero giuridico moderno, 1974-1975, 3-4, p. 557-642.

Schettini, L., Il gioco delle parti. Travestimenti e paure sociali tra Otto e Novecento, Florence, Le Monnier, 2011.

Sellin, T., A New Phase on Criminal Anthropology in Italy, in Modern Crime: Its Prevention and Punishment, Annals of the American Academy of Political and Social Science, 1926, 125.

Sellin, T., The Lombrosian Myth in Criminology, American Journal of Sociology, 1937, 42.

Simonazzi, M., Degenerazionismo. Psichiatria, eugenetica e biopolitica, Milan, Bruno Mondadori, 2013.

Le solenni onoranze a Cesare Lombroso in Verona: la inaugurazione del monumento, 25 settembre 1921, Turin, Bocca 1921.

Spanu, L., Casi lombrosiani, Turin, Fondazione Filippo Burzio - Centro studi piemontesi, 2014.

Spierenburg, P., The Rise of Criminology in Its Historical Context, in Knepper, P., Johansen, A. (Eds.), The Oxford Handbook of the History of Crime and Criminal Justice, Oxford, Oxford University Press, 2016.

Spriano, P., Storia di Torino operaia e socialista. Da De Amicis a Gramsci, Turin, Einaudi, 1972.

Steccanella, V., L'uomo di genio. Scoperta di C. Lombroso, CC, 1895, 46.

Teeters, N.K., Penology from Panama to Cape Horn, Philadelphia, University of Pennsylvania Press, 1946.

Tumiati, C., Vite singolari di grandi medici dell'Ottocento, Florence, Valecchi, 1952.

Van Kan, J., Les causes économiques de la criminalité. Études historique et critique d'étiologie criminelle, Paris, A. Maloine, 1903.

Velo Dalbrenta, D., La scienza inquieta. Saggio sull'antropologia criminale di Cesare Lombroso, Padova, Cedam, 2004.

Villa, R., Letture recenti di Lombroso, Studi storici, 1977, 18.

Villa, R., Il deviante e i suoi segni. Lombroso e la nascita dell'antropologia criminale, Milan, Angeli, 1985.

Viziano, A., Ancora valide le idee di Lombroso creatore dell'antropologia criminale, La Stampa, 7 December 1965, 290.

Walklate, S. (Ed.), Gender and Crime. Critical Concepts in Criminolgy, vol. 1, Sex and Crime or Gender and Crime?, London and New York, Routledge, 2012.

Wanrooij, B., Storia del pudore: la questione sessuale in Italia, 1860-1940, Venice, Marsilio, 1990.

Wetzell, R.F., Inventing the Criminal. A History of German Criminology, Chapel Hill-London, The University of North Carolina Press, 2000. 
Wetzell, R.F., Criminology in Weimar and Nazi Germany, in Becker, P., Wetzell, R.F. (Eds.), Criminals and Their Scientists. The History of Criminology in International Perspective, Cambridge, Cambridge University Press, 2006.

Wolfagang, M.E., Pioneer in Criminology: Cesare Lombroso, Journal of Criminal Law, Criminology and Police Science, 1961a, 52, p. 361-391.

Wolfagang, M.E., Cesare Lombroso, Quaderni di Criminologia Clinica, 1961b, 1.

Woods, J.B., The Birth of Modern Criminology and Gendered Constructions of Homosexual Criminal Identity, Journal of Homosexuality, 2014, 62, p. 1-36.

Ystehede, P.J., La Scandinavia, in Motaldo, S., Tappero, P. (Eds.), Cesare Lombroso cento anni dopo, Turin, Utet, 2009.

\section{NOTES}

1. Lombroso (1911, p. XI). The book was published posthumously, two years after Lombroso's death.

2. C. Lombroso (1907a, 1907b); Comptes-rendus (1908, p. XXXI-XXXVI).

3. Lombroso (1911, p. XIV-XV).

4. Milicia (2014).

5. Lombroso, P., Lombroso, G. (1906); Kurella (1910 and 1911); Lombroso, G. (1915).

6. Goring (1913). Further broadening the field to cover Lombroso's impact in Latin America - which was undoubtedly significant - would have gone beyond the limits of this article and the expertise of its author.

7. Lombroso (1915, p. 118-123).

8. Lombroso (1915, p. 118, 134, 176-177).

9. Lombroso (1904); Frigessi (2003, p. 291-326).

10. Dolza (1991); Babini (2007).

11. Kurella $(1910,1911)$. Havelock Ellis, the man responsible for disseminating Lombroso's ideas in England, collaborated on the translation of the book, which was principally the work of Paul Eden.

12. Kurella (1911, p. 129).

13. Antonini (1900); Morselli (1908, p. 1-31); Marro (1908, p. 175-192); Ferri (1909).

14. Michels (1911, p. 353-367).

15. Papini, Prezzolini (1906, p. 151-159).

16. Franco (1890, p. 285-311); Salis Seewis (1892, p. 143-153, 400-411); Franco (1893, p. 535-537); Steccanella (1895, p. 5-18); Il pregiudizio anticlericale in Italia ("Anticlerical Prejudice in Italy", 1906, p. 142-146); Nani (2006, p. 168-169).

17. Archive of the Cesare Lombroso Museum of Criminal Anthropology (AMACCL), Turin, Fondo Cesare Lombroso (FCC), Letters and condolance cards, 1909. See also: G.C. (1909); Orano (1909); Come Lombroso intendeva il socialismo ("How Lombroso Understood Socialism", 1909); Ai giovani ("To the Youth", 1909); Commemorazione di C. Lombroso ("Remembrance of C. Lombroso", 1909); La salma di Lombroso a Verona ("The Remains of Lombroso in Verona", 1909).

18. L'opera di Cesare Lombroso ("The Works of Cesare Lombroso", 1909); I giudizi di Padre Gemelli ("The Judgments of Father Gemelli", 1909).

19. La conferenza di Padre Gemelli ("The Conference of Father Gemelli", 1910); Gemelli (1910).

20. Gentile (1909, p. 262-274); Croce (1928, p. 133-151).

21. Germinario (2009, p. 36, 47-50, 52); Finzi (2011, p. 49-80).

22. Papa (1958, p. 97-98, 100-101, 150, 132, 135, 138). 
23. Goetz (2000, p. 127-139, 221-222).

24. Forti Lombroso (1945); Forti Lombroso (1969, p. 67-79); Dolza (1991); Gerbi (2016, p. 193-196).

25. M. Ca. (1929, p. 590-596); Carrara (1934, p. 671-691); Lombroso (1935); AMACCL, Ferrero Donation, Gina Lombroso Fund, no. 30, Forti Lombroso, S., Marcia delle dottrine lombrosiane dopo la morte di Lombroso ("March of the Lombrosian Doctrines after the Death of Lombroso"), typescript, undated.

26. Carrara et al. (1937, p. 267, 288, 313-314, 338).

27. Sellin (1926, p. 233-242); Monachesi (1936, p. 396-406).

28. Gibson (2002).

29. Montaldo (2017, p. 175-203).

30. I cimeli scientifici di Cesare Lombroso ("The Scientific Relics of Cesare Lombroso") (1933, LIII, p. 495-496).

31. Maggiore (1938, p. 31-32).

32. Guarnieri (2013, p. 126).

33. Solenni onoranze (1921); Historical Archive of the Commune of Verona (ASCV), Acts of the podestà, no. 625, 29 December 1942.

34. Lombroso Ferrero (1921); Lombroso (1924), Lombroso (1940).

35. Goring (1913, p. 14-16); Aschaffenburg (1913, p. 6, 32, 88, 92, 138, 161, 168-172, 183, 198-199, 205-206).

36. Van Kan (1903, p. 52-143).

37. Bonger (1905, p. 134-203).

38. Lottin (1912, p. II, 285).

39. Lindesmith, Levin (1937, p. 653-671).

40. Rafter (2009a, p. 277-287); Fijnaut (2017, p. 376).

41. Petit (2007, p. 829-831)

42. Simonazzi (2013, p. 136-146).

43. Mannheim (1936, p. 38-45); Rafter (2009b, p. 353-360).

44. Fijnaut (2017, p. 358-359).

45. Fijnaut (2017, p. 417).

46. Parsons (1926, p. 24); Saldana (1933, p. 333-350); Mannheim (1936, p. 31-49)

47. Bonger (1937).

48. Lindesmith, Levin (1937, p. 659).

49. Lindesmith, Levin (1937, p. 666-667).

50. Lindesmith, Levin (1937, p. 668-670).

51. Lindesmith, Levin (1937, p. 671).

52. Sellin (1937, p. 897-899).

53. Teeters (1946, p. 17-22).

54. Hooton (1939, p. 12-13, 16-17)

55. DeLisi (2013, p. 14-16); Raine (2013, p. 1-4).

56. Wolfagang (1961, p. 361).

57. Wolfagang (1961).

58. Wolfgang (1961b)

59. Dunnage (2017, p. 365-384).

60. Monachesi (1936, p. 400-404).

61. ASCV, Acts of the Commune Council, 9 November 1948, no. 117; Serie Carteggi, no. 25203/1947.

62. Babini (2009, p. 129).

63. "Aperto dal ministro di Grazia e Giustizia il congresso nazionale di criminologia" ("The National Conference of Criminology Opened by the Minister of Grace and Justice"), L'Arena, 20 
October 1959; "Fin dai sei anni occorre prevenire la tendenza a diventare 'teddy boy" ("The Tendency to Become a Teddy Boy Must be Predicted from Six Years On"), ibid.

64. Tumiati (1952, p. 69-79).

65. Bellassai (2006, p. 109-116).

66. Viziano (1965).

67. Foot (2014).

68. Basaglia, Ongaro Basaglia (1971).

69. Lombroso (1971, p. IX).

70. Pirella (1971, p. XVI).

71. Sbriccoli (1973, p. 647, 650-652, 673, 683-696), Sbriccoli (1974-1975, p. 578-581, 620, 634).

72. Foucault (1999, p. 142-143).

73. Foucault (1999, p. 275-301).

74. Heidensohn (1968, p. 165-170); Rock (2007, p. 117-133); Walklate (2012, p. 9-39).

75. Brown (1986, p. 387).

76. Gould (1981).

77. Mosse (1978, p. 83-87).

78. Pick (1993, p. 110-152); Gadebush Bondio (1995); Wetzell (2000, p. 15-71, 125, 176, 191, 295-302); Wetzell (2006, p. 401-423).

79. Gadebush Bondio (2009, p. 213-234).

80. Israel, Nastasi (1998, p. 76-77, 101-102).

81. Gramsci (1930).

82. Gramsci (1977, II, p. 879; III, p. 2279).

83. Salvadori (1981, p. 184-205).

84. Spriano (1972, p. 35-45).

85. Lombardi Satriani (1974, p. 135).

86. Lombardi Satriani (1974, p. 180-181); Lombardi Satriani (1978, p. 61-67). Gramsci's verdict on positivist criminology is currently being rediscovered by scholars applying the interpretative models of postcolonial studies and subaltern studies to the history of Italy after unification. In addition, a broader look at the problem was at the centre of a recent conference investigating Italian racism over the long term. On this see Aramini, Bovo (2018).

87. Maristany (1973); Peset (1975).

88. Becker (1978).

89. Chan (2001).

90. Asor Rosa (1975, p. 895).

91. Colombo (1975).

92. Bulferetti (1975, p. 145-146, 235, 309).

93. Bulferetti (1975, p. 343-351).

94. Bulferetti (1975, p. 71, 120, 356).

95. Villa (1977, p. 242-252).

96. Villa (1985).

97. Levra (1985).

98. Peset (1983, p. 154-182, 202-218).

99. Gallini (1983, p. 203-205, 214, 222-229, 234-270).

100. De Bernardi (1984, p. 109-113, 121-123).

101. Mangoni (1985).

102. Gibson (1986).

103. Babini, Minuz, Tagliavini (1986).

104. Dolza (1991).

105. Gibson (1990, p. 11-41), Horn (1995, p. 109-128).

106. Harrowitz (1994). 
107. Baima Bollone (1992).

108. Wanrooij (1990, p. 23, 38, 144, 173-174); (Milletti (1994, p. 50-122); Rafter (1992, p. 525-545); Mucchielli (1994); Gadebush Bondio (1995).

109. Lombroso (1995).

110. Mangoni (1995, p. 685-709).

111. Giacanelli (1995, p. 5-43).

112. Frigessi (1995, p. 333-373).

113. Garin (1995); Pogliano (1995, p. 708-715).

114. Horton, Rich (2004); Rafter, Gibson (2004); Rafter, Gibson (2006); Lombroso (2008); Lombroso, Ferrero (2009); Lombroso (2010); Rodler (2011); Rodler (2012); Lombroso (2013); Palano (2014); Baima Bollone (2017).

115. Becker (2010, p. 33-51); Granieri, Fazio (2012, p. 173-192); Musumeci (2012); Butler et al. (2018).

116. Guarnieri (2000).

117. Gibson (1998, p. 99-115); Dickie (1999, p. 2-5); Petraccone (2000, p. 154-159, 164-167, 285-288); Nani (2006, p. 138-152).

118. Rondini (2001); Berré (2015).

119. D'Antonio (2001, p. 281-309).

120. Martucci (2002).

121. Palano (2002, p. 50-95, 107-123), Bosc (2007).

122. Gibson (2002).

123. Frigessi (2003)

124. Girardi (2016).

125. Ficarra (2016).

126. Horn (2003).

127. Hagner (2004); (Mazzarello (2005); Dahlkvist (2015, p. 587-609); Gentile (2017).

128. Velo Dalbrenta (2004); http://www.publifarum.farum.it/n01.php.

129. Wetzell (2000); Davie (2005).

130. Garton (2006), Salvatore (2006); Nakatami (2006).

131. Mantovani (2004); Cassata (2006); Caplan (2006); Mucchielli (2006); Simonazzi (2013), Petrizzo (2016), Montaldo (2018).

132. Rafter (2008); Salomoni (2009, p. 249-261); Ystehede (2009, p. 263-267); Mogilner (2013, p. 331-344); Spierenburg (2016, p. 373-395); Fijnaut (2017); Nicolosi, Hartmann (2017).

133. Compare, for example, Marchetti (2009, p. 1009-1080) and Garfinkel (2016).

134. Benadusi (2005, p. 39-47); Schettini (2011, p. 178-181); Beccalossi (2012, p. 117-146); Beccalossi (2013, p. 303-325); Woods (2014, p. 131-166).

135. Diemoz (2011, p. 117, 142-143, 147-157, 203); Calafato (2017, p. 78-105).

136. Morehead (2011, p. 102-126).

137. Govoni (2010, p. 95-122); Guarnieri (2006, p. 253-284).

138. Spanu (2014); Montaldo (2016, p. 183-199).

139. Montaldo (2015).

140. Montaldo, Tappero (2009).

141. Knepper, Ystehede (2013).

142. Montaldo (2010); Picotti, Zanuso (2011).

143. Milicia (2014).

144. http://lombrosoproject.unito.it/index.php. 


\section{ABSTRACTS}

This article outlines, for the first time, the main junctures in the historical memory of Cesare Lombroso and of the scholarly interpretation of his legacy, from his death in 1909 to the present. As someone whose life placed him at the centre of significant controversies, and as the symbolic figure of Italian positivism, Lombroso's legacy has repeatedly been the object of conflict and been used to support various causes, through a period marked by profound and dramatic change. Historiographical reflection on his position within the human sciences, however, particularly in Italy and the United States, is of much more recent advent, and is still ongoing.

Cet article décrit, pour la première fois, les principales étapes constitutives de l'héritage historique de Cesare Lombroso et de l'interprétation savante de son œuvre, de sa mort en 1909 à nos jours. De son vivant, il a été placé au centre d'importantes controverses. Depuis lors, le legs intellectuel de cette figure symbolique du positivisme italien a été à plusieurs reprises l'objet de controverses et a été utilisé à l'appui de diverses causes, marquées par les changements d'époque. La réflexion historiographique sur la place de Lombroso dans les sciences humaines est cependant beaucoup plus récente et est en cours, en particulier en Italie et aux États-Unis.

\section{AUTHOR}

\section{SILVANO MONTALDO}

Dipartimento di Studi Storici

University of Turin

silvano.montaldo[at]unito.it 